\title{
小特集 小形カラーカメラ
}

\section{1. 放送用小形カラーカメラの最近の動向}

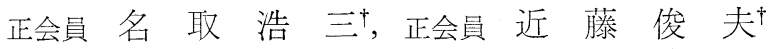 \\ 正会員武田好 男 ${ }^{\dagger}$, 正会員鈴木哲 ${ }^{\dagger}$
}

\section{1. まえがき}

最近の放送用小形カラーカメラ（以㖟ハンディーカメ ラという）の発展は，極好て著しい．

$2 / 3$ インチ撮像管の開発や，ハイブリッド IC による 回路の集積化の技術など，エレクトロニクスの発達は, 小形軽量で, 低消費電力の高性能なカラーカメラをむた らした。

一方, 番組制作の多様化とそのニーズの増加から, 八 ンディーカメラによる番組制作は，乙て数年急速に伸び て来ている. 一例として NHK 地方局の場合を見ると， この 2 年間に約 2 倍の伸びを示している.

こ机は小形軽量化住りり, 単化運用性, 操作性が向上 したためだけではなく、テレビ番組に質的変化をむたら しつつあるからである。すなわち，小形軽量の利点を生 かした機動性と多彩なカメラワークは, 新しい映像表現 の手段として, 番組の内容を深め, その評価が急涑隹高 まって来ているためである。

ハンディーカメラは従来，一般番組制作での運用が多 かったが，最近ではむうひとつのニーズとして 1 カメ -1 VTR 運用の機動性に富んだ ENG システムとして発 展してきている.フィルム取材が主流を占めたニュース 取材分野への導入が急速汇進んで扔り，ハンディーカメ ラの需要にさらに加速がついた状況にある.

\section{2. 撮 像 管}

今日に招ける放送用としての高性能小形カメラの発展 は，小形で高性能な撮像管の開発汇負うところが多い.

ハンディーカメラではサイズの小さな撮像管ほどカメ ラを小形にまとめることができるため，2/3 インチ撮像 管が多く使用されている. 現在, $2 / 3$ インチ撮像管として 放送用小形カメラに用いられているすのは，サチコンと プランビコンにほぼ限定される。 サチコンH8397Aは，

\section{$\dagger$ NHK 技術本部}

"Recent Developmental Trends of the Portable Color Television Cameras for Broadcast Use" by Kozo Natori, Toshio Kondo, Yoshio Takeuchi and Tetsuo Suzuki (NHK Engineering Headquarters, Tokyo)

解像度の良さとフレアーが少ない特長があり, 一方, サ チコンに比して解像度がやや劣ることが久点とされて いたプランビコンも, ダイオードガン XQ 2427 の開発1 により解像度特性の改善が図られた。また, 最近, 小形 カメラの SN 比改善の一環として撮像管の実装状態での 出力容量を減少させるために, 信号の引き出し構造を従 来のターゲットリング方式ではなく, 導電膜に直接ピン を接続し，信号電極上した，ピンリード方式撮像管の使 用む試みられている。乙れにより出力容量が $3.5 \sim 4 \mathrm{pF}$ 減少し, 小形カメラの $S / N$ 改善に寄与している.

小形カメラのなかでも, ENG カメラはさらに小形で 操作性の良いととが要求される. NHK では, 2/3 イン チサチコンの全長を $20 \mathrm{~mm}$ 短縮した短縮形サチコンを 開発, ENG カメラに使用している2). 短縮長は, 短縮 によるカメラ形状の改善, 操作性の向上, 重量軽減など の効果と, 周辺変調度の低下などの特性低下とのバラン スで決定された。

さらに小形化という点からは, 放送用単管カメラや, $1 / 2$ インチ撮像管の開発が考えられる, 最近, 単管カメ ラの画質, 性能向上は著しいむのがあるが，放送用とし ては, 亦の色再現, $S / N$, 解像度などの点で, いっそう の性能改善が望まれる.しかし小形軽量でコンパクトで あるほか，経済性の面であ有利であるので，今後 ENG

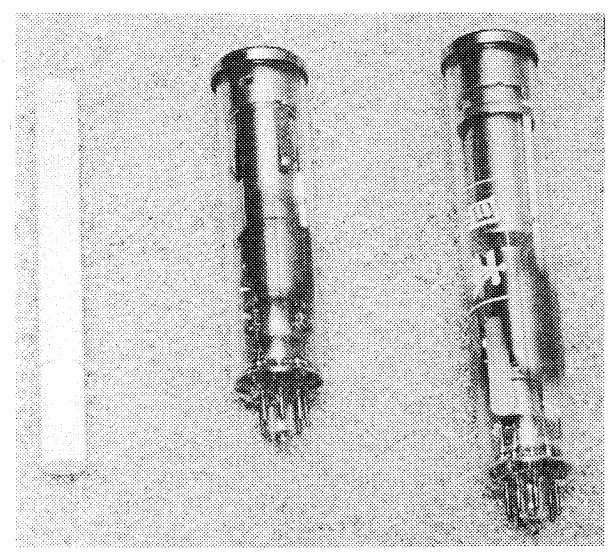

写真 1 短縮形サチコン 


\section{1. 放送用小形カラーカメラの最近の動向}

の分野などで，実用への改善を図りながら使用されてい くことが考えられる.

また，撮像管と一体の働きをするコイルアセンブリー についてむ, 軽量化，小形化の試みがなされている，最 近のハンディーカメラでは, インナーフォーカス形コイ ル（フォーカスコイルが，偏向コイルの内側に巻かれて いるタイプ）が多用されている. アウターフォーカス形 コイルに比ベて，コイル外径寸法が約 $5 \mathrm{~mm}$ 前後減少, 重量比で約 $30 \%$ 程度軽量化されているため, ハンディ 一カメラの小形化, 重量軽減に効果がある.

撮像管の集束および偏向方式は，放送用小形カメラの 場合，現状は Mag-Mag の方式がほとんどであるが， さらに解像度特性の向上，小形・低消費電力化を図るた

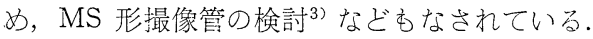

一方，固体撮像デバイスは，撮像管に比べて長寿命で， 性能面でむ，図形ひずみ，焼付きが少なく，小形軽量で 低消費電力化に向くなど多くの利点があるため, CCD を中心に活発な研究開発が進められており，最近のむの では画素数 $492(\mathrm{~V}) \times 660(\mathrm{H})$ で，撮像管に近い解像度 を得た報告4 あある。

しかし現状では，感度，素地むらや，ブルーミングな ご技術的課題む多く，放送用としての実現はまだ先のこ 亡と思える。

\section{3. 光 学 系}

カメラの光学系は色分解系とズームレンズに分けられ る. 色分解光学系にはリレータイプとプリズムタイプの 2 種類がある. 前者の特長としてテーキングレンズのバ ックフォーカス長が短い, カメラの重心位置やレジスト レーションに及ぼす地磁気の影響に対して有利なことな どの利点がある。一方, 後者は専用のズームレンズを使 用しなければならない欠点はあるが，コンパクトにで き，機械的衝撃に対して安定であることから，最近の八 ンディーカメラにはほとんよ゙このタイプの光学系が使用 されている. 以下，ズームレンズとプリズムタイプ色分 解系を中心に述べる.

\section{1 ズームレンズ}

ハンディーカメラが開発されたころは使用できるズー ムレンズの種類む限られていたが, 最近の ENGの急速 な進歩と相まって交換レンズ用の長焦点レンズを含め, 目的に合ったレンズをある程度選択できるようになりつ つある。

現在スタジオなどで実用されている 1 インチ標準カメ ラ用レンズを $2 / 3$ インチに換算した等価レンズを考えて みると，焦点距離のワイド側が 8.4 11 mm，最大口径 比 (以下 $F$ 值という) 1.1〜1.3 程度となる. 乙れに対し
て現状の $2 / 3$ インチレンズの $F$ 值は, 明るいレンズです 1.6 程度あり, この点では標準カメラに比べて劣ってい る.

一方，八ンディーカメラの基本的要求である小形軽量 化についての進歩は目覚しいものがある. 数年前のズー ム比 10 倍のレンズよりも現在の 13〜14 倍のレンズの方 が俥量化されているのはそのよい例であり, 今後む, こ の努力は続けられるだろう。

また，ハンディーカメラの撮像条件の多様性をカバー するために，エクステンダー内蔵形のズームレンズが増 えてきているのも最近の傾向である.しかし，現状では さらにワイド側掞よび長焦点側をカバーするレンズの開 発はまだ充分ではない。ささら，標準カメラとの混用や 標準カメラと同等に使用されることが多くなるに従い, 小形軽量化のためにややすすれば軽視されていたレンズ の性能 (明るさ, 光学ひずみ, 解像度など) を改善した ハンディーカメラ用高性能ズームレンズの要望が增える ことが予想される。

\section{2 プリズム}

色分解系プリズム（フィリップス形プリズム）として 従来 BK-7 プリズム（屈折率う1.52）が用いられてきた が，ハンディーカメラの小形軽量化の要求を満たずため ハイハンデックスプリズム(屈折率 $\fallingdotseq 1.70$, 以下 H. I と

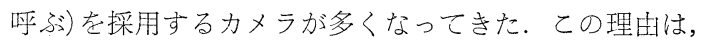
性能面で BK-7 とほぼ同程度のむのができるようにな ったとと, カメラの小形軽量化に対するメリットが大き いことなどがあげられる。

一般にプリズムの大きさおよび形状は（i）テーキン グレンズの $F$ 值およびロ径蝕に対する余裕度のとり方,

(ii）プリズムの屈折率, （iii）コイルアセンブリーの形 状，（iv）ゴースト対策，などにより決定する.

初期のハンディーカメラでは F1.6のプリズムが使用 されたととああるが，現在はF1.4が一般的である。

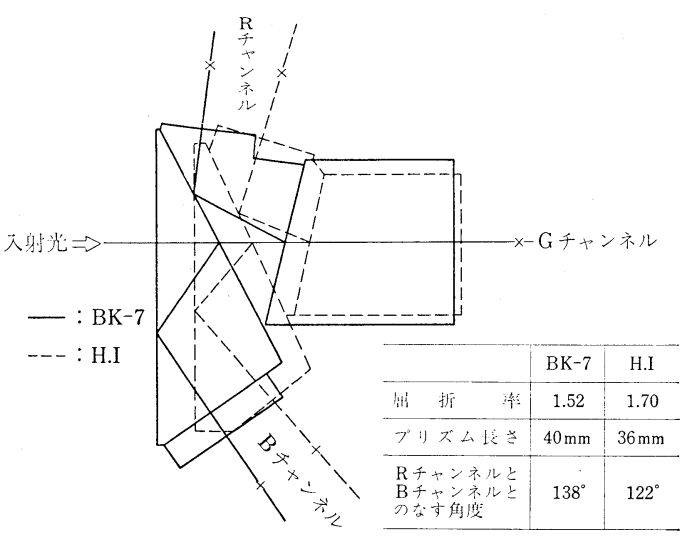

図 1 2/3 インチ撮像管用プリズムの形状比較 


\section{小特集 $\square$ 小形カラーカメラ}

れは小形化を要求する場合は不利な要因である。 そこで

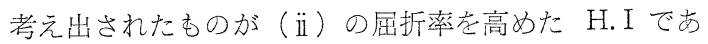
る. H. I を使用すると, プリズムの幅, 長さとすに約 4 $\mathrm{mm}$ 短くするてとができる。ささらに副次的効果上して図 1 亿示すようにRチャンネルと $\mathrm{B}$ チャンネルのなす角度 が小さくできるため, カメラの高さ方向約 $18 \mathrm{~mm}$ (撮 像管の長さを $112 \mathrm{~mm}$ とした場合）短縮できる。また， プリズムの幅方南が小さくなるためフィルターターレッ トの外形寸法, さらにはカメラの幅寸法を縮めるのに役 立つ。

重量を考えた場合は, 高屈折率ガラスの比重が重いた めプリズム自体では数グラム軽くなるだけであるが，プ リズムハウジング, フィルターターレット，カメラ外形 寸法などの小形化を考慮すれば, カメラとしての重量差 は無視できない.

以上のような利点をむつ H.I む万能ではない. バイ アスライト，ゴーストおよびフレアの性能では BK-7 に 比べて不利である ${ }^{5)}$.しかし，乙れらの問題も蒸着技術， プリズム外周処理技術の進歩により, 最近では BK-7 と ほぼ同程度になってきた。な㧍，短波長側の透過率に若 干劣性の部分も残っているが，小形軽量化のメリットが 大きいととから今後も多用されることにならう。

\section{4. 自動システム}

ハンディーカメラは, 運用条件が広範囲にわたるうえ, 標準カメラのように完備されたモニター機器によりセッ トアップ調整および運用中のオペレーションが行われる 機会は少ない，多くの場合，カメラマンが白黒ビューフ アインダーだけを頼りにカメラの動作状態を磼認しなけ ればならない.このため, 自動調整機能が不可欠であ る. 現在多くのハンディーカメラには,オートアイリス, オートホワイトバランス, オートブラックバランスが装
備されており,さらに一部のカメラには, オートセンタ リングの導入が罒られている。

\section{1 オートアイリス}

オートアイリスは, 映像を平均值またはピーク検波し てレンズアイリスを目動制御するすので，その応答特性 をいかに自然なすのをするかがポイントである，そのた め，検波回路への入力映像信号にゲートをかけ画面周辺 の不要な信号（例えば太陽光とか照明用ライト光など） をカットしたり，画面位置によって検波感度を変えるな どの回路姏理を施し，通常の画面では，ほぼ満足できる 応答特性を得ている。

オートアイリスに関連してカメラおよびレンズの機種 の増加㲹伴い, カメラとレンズ間の互換性が重要な課題 となっている、レンズマウントの形状, レンズ制御電圧, アイリス制御方式，レンズコネクターなどがメーカー間 により異なるため運用上不便をきたしており，何らかの 規格統一が望まれる.

\section{2 オート色バランス}

良好な色バランスを得るために，オートホワイトバラ ンスとオートブラックバランス回路が設けられている.

オートホワイトバランスは, 照明光源の色温度変化に応 じてカメラのホワイトバランス調整をワンタッチで自動 設定する機能で，利得制御範囲は，Gチャンネルを基準 に 4 6 $\mathrm{dB}$ あり, 3,000 K 設定で, 4,500 600 K 程度 まで色温度変換フィルーなしでカバーできる. 利得制御 電圧は，コンデンサーまたは，ディジタル IC などにメ モリーされ，運用中その電圧值を保持する，一方，ブラ ックバランスは, 入射光がない状態で备チャンネルの黒 レベルを一致させる機能である. 黒レベルの変動は色バ ランスに大きく影響するが，放送用カメラの仕様である $-20 \sim+50^{\circ} \mathrm{C}$ という使用温度範囲で常に一致させるこ とが難しいため，ての機能が設けられている.

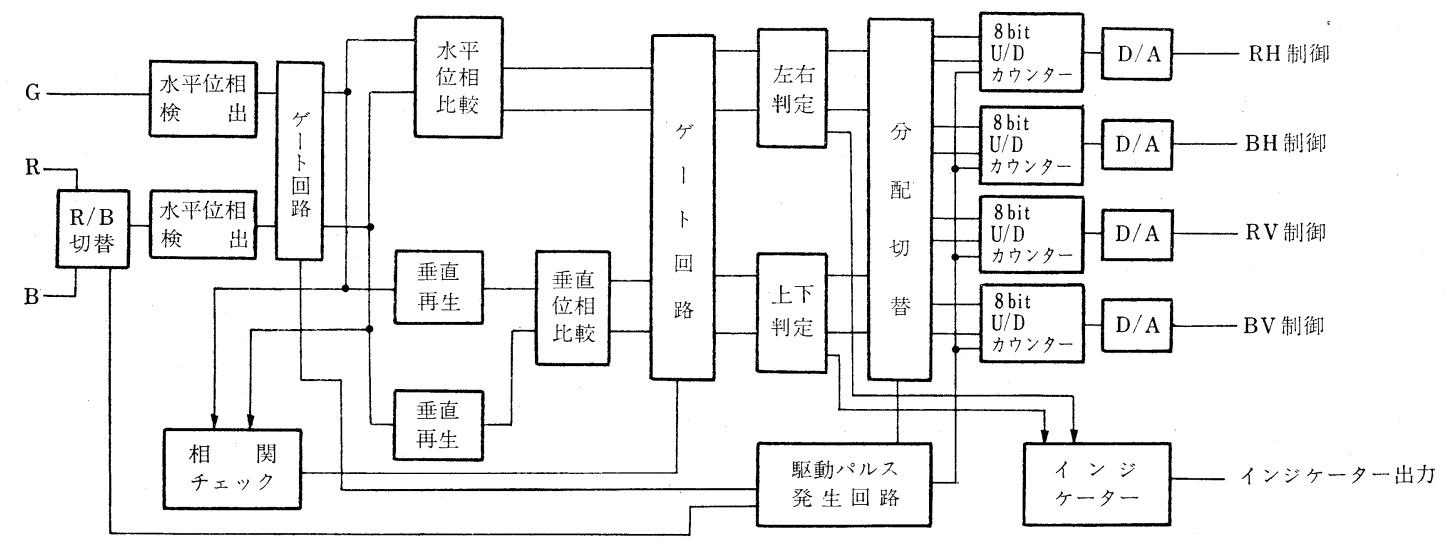

図 2 オートセンタリング回路例 


\section{3 オートセンタリング}

3 管式のハンディーカメラでは，レジストレーション の安定度が, カメラの定期整備のインターバルを決定す る大きな要因となっている. 現在のハンディーカメラに おけるレジ変動は, 電気回路部の変動によるものより光 学系およびコイル支持機構の温度変化に伴う機械的ひず みのために生ずるセンタリング変動が大きい，乙の変動 を自動補正するために，従来の標準カメラのオートセッ トアップ装置で用いられている特殊パターンを使用した 精密なレジ調整機能ではなく, 通常の被写体から輪郭成 分を検出，センタリングのみを簡便り補正するオートセ ンタリングの開発が行われており6)，すでに実装したハ ンディーカメラも発売されている7). オートセンタリン グ回路の一例を図 2 に示す.

\section{4 オートフォーカス}

レンズの焦点あわせの自動化を図ったオートフォーカ スレンズが写真機用レンズに採用され，さらに民生用テ レビカメラに応用の動きがある. その測距原理から, 放 送用カメラへの適用範囲は限られるが, とりあえず一定 の制約条件のあとで運用性の検討を図りながら，ENG カメラなどでの使用について検討されるだろう.

\section{5 オートセットアップ}

今後, ENG カメラを含む小形カラーカメラの台数は, さらに急増することが予想され, その性能の効率的な維 持管理は重要な問題である. したがって, ハンディーカ メラ用のオートセットアップ機能は, 単なる初期調整機 能だけではなく, 故障診断やバッテリーの残量管理なよ゙ を含む総合的なシステム管理の発想が必要であり，その

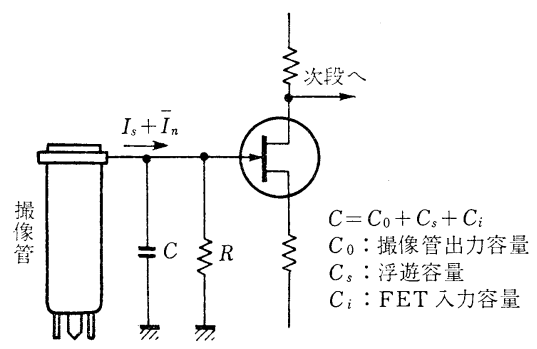

図 3 カメラの初段回路

ための検討, 開発が進められている

\section{5. 画 質}

ハンディーカメラはその機動性のゆえに屋外での㛜し い被写体条件での撮像を要求され，種々の改善がなされ てきた. 表 1 に最近の主な小形カラーカメラの性能を示 すे.

\section{$5.1 S / N$}

カメラの $S / N$ は, 周知のとおり初段増幅器 の $S / N$ によりほとんど決定される。図了に示す初段回路に沶い て，S/N は次式で表わされる ${ }^{9)}$.

$$
S / N=\frac{I_{s}}{\sqrt{\bar{I}_{n}^{2}+4 k T B\left[\frac{1}{R}\left(1+\frac{R_{e}}{R}\right)+\frac{4}{3} \pi^{2} C^{2} R_{e} B^{2}\right]}}
$$

ただし， $I_{s}$ : 信号電流， $\bar{I}_{n}$ : 撮像管ショットノイズ, $R$ : 負荷抵抗, $R_{e}: \mathrm{FET}$ 等価雑音抵抗, $C$ : 並列容量, $k$ : ボルツマン定数, $T$ : 温度, $B$ : 帯域幅

したがって， $/ N$ を改善するためには（i） $R_{e}$ の小

表 1 主な小形カメラの性能一覧

（各社カタログから抜粋）

\begin{tabular}{|c|c|c|c|c|c|c|c|c|}
\hline 形 名 & xーカー & 像 & 光 学 系 & 感 & オート機能 & $\left|\begin{array}{c}\text { 重量本体 } \\
+\mathrm{VF} \\
(\mathrm{kg})\end{array}\right|$ & $\begin{array}{l}\text { 学費電力 } \\
\text { (W) }\end{array}$ & その 他 \\
\hline SK-91 & 日立 & $\begin{array}{l}\text { 2/3"サチコンまた } \\
\text { ンビコン }\end{array}$ & H.I. プリズム & $\begin{array}{l}2000 \mathrm{~lx} \\
F 4.0 \\
56 \mathrm{~dB}\end{array}$ & $\mid \begin{array}{l}\text { オートアイリス } \\
\text { オートホワイトバランス } \\
\text { オートブラックバランス }\end{array}$ & 4.4 & 22 & $\begin{array}{l}\text { 自動ビーム調整機 } \\
\text { 能付 }\end{array}$ \\
\hline $\mathrm{HL}-79 \mathrm{~A}$ & 池上 & 2/3" プランビコン & \begin{tabular}{|l}
$\mathrm{BK}-7$ \\
プリズム
\end{tabular} & $\begin{array}{l}2000 \mathrm{~lx} \\
F 5.0 \\
54 \mathrm{~dB}\end{array}$ & $\begin{array}{l}\text { オートアイリス } \\
\text { オートホワイドランス }\end{array}$ & 5.1 & 23 & 同上 \\
\hline HL-79D & 池上 & $\begin{array}{l}2 / 3^{\prime \prime} \text { ダイオードガンプラ } \\
\text { ソビコン (LOC) }\end{array}$ & 同上 & $\begin{array}{l}2000 \mathrm{~lx} \\
F 4.5 \\
57 \mathrm{~dB}\end{array}$ & 同上 & 同上 & 同上 & $\begin{array}{l}\text { 自動ビーム調整機 } \\
\text { 能付ダイナミミック } \\
\text { フォーカス付 }\end{array}$ \\
\hline MNC-81 A & 日電 & $\begin{array}{l}\text { 2/3"サチコンまたはプラ } \\
\text { ソビゴン゚多イオード } \\
\text { ガンプランビコン }\end{array}$ & H.I & $\begin{array}{l}2000 \mathrm{~lx} \\
F 5.0 \pm 0.5 \\
54 \mathrm{~dB}\end{array}$ & 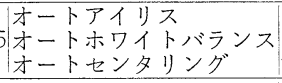 & $\begin{array}{c}\text { 約 } 4.5 \\
\text { 本体のみ }\end{array}$ & 約 24 & $\begin{array}{l}\text { 自動ビーム調整機 } \\
\text { 能付 }\end{array}$ \\
\hline PK- 60 & 東芝 & $\begin{array}{l}\text { 2/3"プランビコンまたは } \\
\text { ダイオードガンプランビ } \\
\text { コン }\end{array}$ & t) & $\begin{array}{l}2000 \mathrm{~lx} \\
F 4.5 \\
54 \mathrm{~dB}\end{array}$ & $\begin{array}{l}\text { オートアイリス } \\
\text { オートホワイドランス }\end{array}$ & 4.5 & 20 & 同上 \\
\hline BVP-300A & ソニ - & $\begin{array}{l}\text { 2/3"サチコンまたはプラ } \\
\text { ソビコン }\end{array}$ & 同上 & $\begin{array}{l}20001 \mathrm{x} \\
F 4.7 \\
56 \mathrm{~dB}\end{array}$ & $\mid \begin{array}{l}\text { オートアイリス } \\
\text { オートホワイドランンス } \\
\text { オートブラックバランス }\end{array}$ & 5.6 & 21 & 同上 \\
\hline BVP-330A & ソニ- & $\begin{array}{l}\text { 2/3"ダイオードガンプラ } \\
\text { ンビコン }\end{array}$ & 同上 & $\begin{array}{l}20001 \mathrm{x} \\
F 4.5 \\
52 \mathrm{~dB}\end{array}$ & $\begin{array}{l}\text { オートアイリス } \\
\text { オートホワイドランス } \\
\text { オートブラックバランス } \\
\text { オートセンタリング }\end{array}$ & 5.3 & 24 & 同上 \\
\hline KY -2000 & ビクタ & -2/3" サチコン (St-Mg 形) & $\mid \begin{array}{l}\text { |゙イクロロイッ } \\
\text { グミラー }\end{array}$ & $\begin{array}{l}25001 \mathrm{x} \\
F 4.0 \\
52 \mathrm{~dB}\end{array}$ & $\begin{array}{l}\text { オートアイリス } \\
\text { オートホワイドランス }\end{array}$ & 5.6 & 18 & \\
\hline
\end{tabular}




\section{小特集 $\square$ 小形カラーカメラ}

さな FET を選ぶ，（ii）Cを小さくする，等の方法が ある。

（i）の方法については FET の等価雑音抵抗 $R_{e}$ が $g_{m}$ にほぼ比例するととから， $g_{m}$ の大きい FET を選べ ばよい， $g_{m}$ を大きくするひとつの方法として，当初 FET 2 個並列に接続する方法がとられたが，乙の方 法では並列容量 $C$ 屯大きくなってしまい, 最近ではこの 方法は用いら机ていない（1)式を近似すると $S / N$ は ほぼ $\sqrt{g_{m}} / C_{i}$ に比例するととがわかる。すなおち, 初 段の FET としては $g_{m}$ が大きくしかむ $C_{i}$ の小さなむ

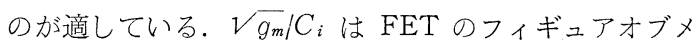
リットと呼ばれ，乙の值の大きな FET が開発, 使用さ れてきた。

（ii）の並列容量 $C$ を小さくする方法として, 撮像管 のターゲットリングから初段 FET までの配線による浮 遊容量を少なくするため, 初段增幅器をコイルアセンブ リー内に実装する方法がある。乙れは近接配置形と呼ば れ, 最近開発されたハンディーカメラの大部分がこの方 法を採用している.さらにCを小さくするため, 前述の ピンリード形撮像管を用いているカメラあある.

一方，S/N を改善する別の方法として，撮像管出力 と初段 FET の間にコイルを挿入するパーシバル回路方 式があるが，並列容量が小さくなったてと，周波数特性 の調整がむずかしいとと等の理由により最近では用いら れていない. ハンディーカメラの $S / N$ は放送用として 初めて本格的に導入された当初は約 $48 \mathrm{~dB}$ 程度であった が，最近のカメラはほとんど $54 \mathrm{~dB}$ 以上であり， $57 \mathrm{~dB}$ のカメラあ実現している.

視感上の $S / N$ 改善として, 低域のクランプ性ノイズ を改善するため, 撮像管出力とプリアンプを直結形とし， レートでクランプしているカメラあある.

\section{2 レジストレーション}

放送用小形カメラとしては, 高画質が得られることか ら大部分 3 管式であるが，乙の方式は本質的にレジスト レーションエラーを有し, 乙机付して高い精度, 安定 度が要求される. 精度の向上については, 撮像管, コイ ルアセンブリーの特性の揃ったものを組沉するなど，品 質管理のうえで向上が図られてきた.

一方, 回路的には偏向コイルに各種補正波形を加える ととによりピンクッションや台形 $\mathrm{S}$ 字ひずみ等も補正で きる回路が開発され，周辺のひずみが大幅に改善されて きた．しかし，乙の方法はたくさんのVRを調整する必 要があり, 調整にかなりの熟練を要する。このため, マ イクロプロセサーを利用し簡単な操作で複合の補正波形 を制御する方法が考案され，全画面でのひずみが $0.05 \%$ 以下のカメラも報告されている10).
このような周辺レジの向上は, ダイナミックフォーカ スと合わせ周辺の解像度向上をもたらしてきており，今 後, レンズの色収差や周辺解像度の向上が望まれてきて いる.

一方, レジストレーションの温度変化住対する安定化 を図るため，プリズムケース内に温度センサーを入れセ ンタリングの変動を補正しているカメラあある.しかし この場合, 変動量が各カメラで異なるため, 最適補正の ためには温度サイクルテストにより1台でとに補正量を 決定しなくてはならない. 地磁気に対しては，コイルア センブリーだけでなくプリズムをも包括してパーマロイ で覆うなど, 磁気シールドの形状や材質の検討が行わ れ，最近では地磁気に対する変動は実用上問題とならな くなってきている.

\section{3 ハイライト対策}

ハイライト撮像におけるコメットテールやブルーミン グおよび燒付きなどは，テレビカメラの解決すべき大き な課題である.

このうち,コメットテールおよびブルーミングは撮像 管のビーム不足に起因するすのであり，乙の解決方法之 してはブランキング期間に多量のビーム電流を流してビ 一ム不足を解消する ACT 管といわれる特殊撮像管を用 いる方法と, 入射光量に応じてビーム電流を增減する方 法がある、ハンディーカメラでは，特殊管を必要とせず 回路的に解決できることから主に後者の方法が採用され てきた.

この方法においても, 単に信号電流を增幅し第 1 グリ ッドに帰還をか壮る方式では，ダイナミックレンジを大 きくすると横縞状の発振を起ししやすく不安定であるた め, ビーム電流と信号電流の差である㞍りビームを一

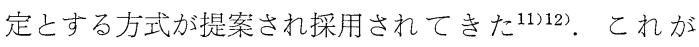
$\mathrm{ABO}$ といわれるあので，8１6 倍の入射光量に対して あ安定で, コメットテールやブルーミングのほとんど認 められない画像が得られるようになった。しなし, 発光 体を撮像した場合等, さらに広いラティチュードが要求 され，今後よりいっそうの改善が望まれるところである.

\section{4 高感度化}

屋外での使用が多い八ンディーカメラでは, 特別な照 明を用いないで撮像できることが要求される。このため 高感度化が進められてきた。

カメラの感度を上げるには, レンズ, プリズム, 撮像 管などの光電変換系の能率を良くする必要がある.プリ ズムの改善としては, 透過率を上げるとともに撮像特性 の肩の部分を持ち上げて上部を平担にする方法がとられ てきた.しかしての方法では撮像特性が変わってくるこ と. Gチャンネルに比べ R, B チャンネルの $S / N$ が悪 
くなることなどから，改善には限界があ $る^{13)}$. 一方, 実効感度を改善する方法と して，レンズのロ径比を大きくしカメラ の $S / N$ を改善する方法がある.

レンズの $F$ 值は当初 $F 2.0$ 程度であっ たが, 最近では F1. 6 となり，プリズム の改善と合わせて最低必要照度は $7501 \mathrm{x}$ から $3501 \mathrm{x}$ に改善されている. 感度切 替機能としては, 当初 $+6 \mathrm{~dB}$ 程度が実 用可能限界であったが， $S / N$ 改善など により最近では $+18 \mathrm{~dB}$ の感度切替を持 ったカメラむあり, 約 $50 \mathrm{~lx}$ 程度の明る さでむ撮像可能である.

一方, 月明り程度 (約 $41 \mathrm{x}$ ) での撮像 が可能なカメラとして，SIT 管を用いた

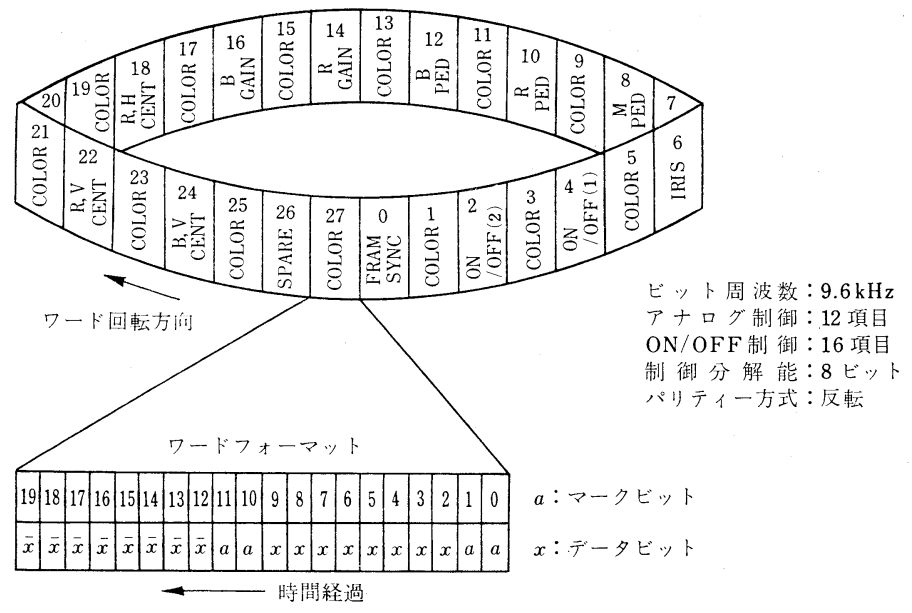

図 4 ディジタルコマンド信号のデータフォーマット例 ハンディーカメラむ開発された. しかし，乙のカメラは ハイライト部分のブルーミングや SIT 特有のノイズの ため，その使用には制約がある.

また最近，感度， $S / N$ の点で標準ハンディーカメラ とSIT を用いたハンディーカメラの間を埋める機種と して，201x 程度まで撮像可能な I. I 付きのハンディー カメラも開発された ${ }^{14)}$. しかし, これらの高感度力メラ は画質, 重量の点で今後解決すべき問題がある.

\section{6. ディジタルコマンドシステム}

ハンディーカメラの運用性をより向上させるために, リモートコントロール機能をもり込んだカメラが一般的 である. この機能を満足させるために, ヘッドとリモー トコントロール部を多芯カメラケーブルで接続する方式 が多い，乙の方式は回路が簡単で，ヘッド側の重量増加 がほとんどないという利点む多いが，ケーブルの長さ, 太さ, 重量, 操作性などの制限から次第にディジタルコ マンド方式を採用する機種が増えてきている ${ }^{15)}$.

この方式を利用すれば，へリコなどからの中継に必要 な無線制御, 電話回線を利用した遠方制御にも応用でき, 演出上有利な画面を撮るととが可能となる。ディジタル コマンド方式は制御に必要なデータを時分割で間欠的に 伝送する.したがって, 適当な設計を行わないと操作性 の動作に対する遅れ，および連続動作に対するスムーズ さが問題となるととがある. 基本的にはビット周波数, 制御項目, 分解能, パリティー方式などに左右される.

図 4 は実用化されているデータフォーマット例 ${ }^{16)} あ$ る.との例は GL を含めた制御を常時同一フォーマット で伝送する方式である，とこでカラーデータを1ワード おきに送っているのは, カラーロック時のジッターを許 容值内におさめるための処理方法の一例である. また,

GL 関係を除いた項目のみをディジタルコマンド方式で 制御することで, 間欠制御の欠点を改善したシステムを 実用化している例むある.

\section{7. 伝送方 式}

カメラヘッドとリモートコントロール間を結ぶ方式に は種々考えられるが，ハンディーカメラの特質を発揮す るには, ケーブルの細芯化, 最大使用長の増加は有効な 手段である. このため, 図 5 に示すような周波数多重伝 送技術を利用した方式が多く見られる. その結果, 多芯 カメラケーブルの場合, 最大使用ケーブル長が $300 \mathrm{~m}$ 程 度であったものが，同軸ケーブル $(5 \mathrm{C} 2 \mathrm{~V})$ で $1,000 \mathrm{~m}$, TRiAX ケーブルで $1,500 \mathrm{~m}^{17)}$, 光ファイバーで 3,000 $\mathrm{m}^{18)}$ が実用化され，ますます長距離伝送が可能になっ てきた.

このうち，新しい試みとして光ファイバーを用いた方 式 ${ }^{19)}$ は注目できる.ケーブル重量の軽量化 (5 C $2 \mathrm{~V}$ の $3 / 4$ 程度), 誘導雑音, アース電流の問題がないなどの特 長があり，有望な方式ではあるが，現状では，ひずみ， $S / N$ などの特性面, コネクターでの接続損失の点で同
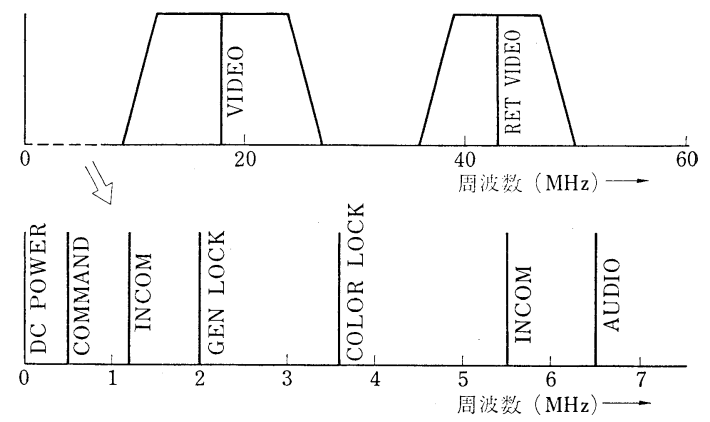

図 5 多重システムの周波数配置例 
軸ケーブルに比べ劣る面があり，今後の改善を期待した い.さらに, 光ファイバーの広帯域性を利用して, クロ マキー信号の伝送を含めた多重伝送システム沉応用でき れば，有用なシステムが完成するだろう。

\section{8. バッテリー}

ハンディーカメラが機動的に運用されるにつれて，電 源は AC アダプターによるよりも2 次電池に依存する てとが多くなってきた。これまで機器の電圧が不統一で あったため電池の管理業務を繁雑なむのにしていたが, 最近になって DC $12 \mathrm{~V}$ (ーアース) 亿統一され，また 形状，コネクタ一等も統一が図られてきている201。 ハン ディーカメラの電池としては, エネルギー密度が高く, 急速充電が可能で, サイクル寿命が長いとと, 経済性が 良く, 維持管理が容易なととなど, が要求される. 現存 の電池ではこれらすべてを満足するむのはなく，それぞ れ長所, 短所を持っているが, 実用されている.

銀系電池は，エネルギー密度が高く，小形軽量化でき るが，サイクル寿命が不安定で，過放電に弱いなど，取 り扱い管理に難点があり，経済性も悪い。ニッケル・カ ドミニウム (以下ニッカド) 電池は, サイクル寿命が長 く, 放電電圧が安定であるが, エネルギー密度が低く, 自己放電む比較的大きい，小形シール鉛電池は経済性が 良く, 急速充電が可能であるが, サイクル寿命が短く, 過放電に弱い.

最近は信頼性の面からニッカド電池が主流となってき ている. ニッカド電池を急速充電するためには, 過充電 時に発生するガスの対策が必要である。このためセルお よび充電器の改善がなされた，七ルの改善としては，耐 過充電タイプとするため, 発生するガスを吸収する補助 電極を設けたり, 極板, 電解液の改善が行われた ${ }^{21)}$. 充 電器の改善としては $1 / 3 \mathrm{C} *$ 以上の急速充電を行う場合, 充電量が $100 \%$ をてえると電圧がやや低下することを利 用して充電制御するすのや, 充電中に時々パルス放電さ せ発生するガスを吸収するすのも報告されている222．

\section{9.むすび}

本稿は, 小形ビデオ機材のうち, ハンディーカメラに ついての現状と問題点と今後を，ユーザーの立場からみ て概説した。

ハンディーカメラの画質, 性能が向上するに従い, 番 組制作面でもハンディーカメラを使った新しい試みがい ろいろなされている。 その結果, 例えば本年度の芸術祭
テレビドラマ部門では，ハンディーカメラ 2 台のみで制 作した「夏の光で」などが受賞するに至っている．また 今日, ニニース取材で ENG の占むめる割合が大幅にふ え, フィルムに比肩するまでになっている.

しかし，テレビ放送システムの中でカメラの占める役 割が重要なだけ,ハンディーカメラのいっそうの小形化, 高性能化化寄せる期待む大きい.

(昭和 55 年 12 月 16 日受付)

\section{〔参 考 文 献〕}

1）荒木, 永山：ダイオードガンプランビコン, テレビ学技 報, 13， 17 (1978) 27-34

2）武内, 鈴木ほか: 短縮形撮像管による小形ハンディカメ ラ, テレビ全大予, 3-9 (1979) 121-122

3）會重ほか：ダイオードガン付 MS 形撮像管の動作実験, テレビ全大予，3-9 (1980) 55-56

4）原田：固体撮像デバイスにおける新技術の動向，同上, 5-2 (1980) 421-424

5）阪井ほか：テレビカメラ用レンズ，テレビ誌，33， 6 (1979) 458-465

6）山本，牛山ほか：ハンディカメラ用オートセンタリング 装置，テレビ全大予，5-2（1980） 87-88

7) 上中田：NAB 大会汇出席して, NHK 技研月報, 23, 9 (1980) $30-36$

8）村上ほか：マイクロコンピューターを用いた小形取材シ ステムメインテナンス (第一報)，テレビ全大予， 5-9 (1980) 101-102

9）和久井ほか：画像電子回路，コロナ社，63-69

10) J. O. Ryan: Recent Advance in Broadcast Camera Design, IBS Rep. (1980) 27-30

11）大西注か： $\mathrm{ABO}$ (自動ビーム最道化回路)の動作とその 解析, テレビ誌, 32, 12 (1978) 1045

12）安口ほか: $A B O$ システムと小形カラーカメラへの応用, テレビ全大予, 3-15 (1978) 75

13）片山：光学系の分光特性のバラツキによる色再現性に与 える影響について，テレビ全大予，5-1 (1980) 85-86

14）大西ほか: 小形高感度カメラの開発とその運用結果, テ レビ全大予, 5-8 (1980) 99-100

15）武内ほか: ディジタルコマンド装置を内蔵した小形ハン ディカメラ, テレビ全大予, 4-7 (1979) 123-124

16）近藤ほか: 万能形ハンディカメラ NHK-III 形, 放送技 術, 32, 8 (1979) 636-642

17）福山活：テレビカメラ，放術技術，33，1（1980）5966

18）藤井ほか：MNC-81 A 形カラーカメラ装置，テレビ全 大予, 5-7 (1980) 97-98

19）大串ほか：光送受信器組込形ハンディーカラーカメラ, テレビ学会放送現業技術資, PROE 23-1 (1980.5)

20）テレビ学会放送現業技術委員会: 放送用ポータブル機器 のバッテリー規格, テレビ誌，33，8 (1979) 666

21）津田ほか：密閉形ニッケルカドミニウム蓄電池の急速充 電特性, National Tech., 24 (1978) 313

22) F. Bentamin: System for 20-Min Recharging of Sealed Nickel Cadmium Batteries, J. SMPTE, 86, 4 (1977) 204-209

\footnotetext{
* 公称容量值を 1 時間で充電する時の電流が $1 \mathrm{C}$
} 